\title{
Reactive Barriers for Renaturalization of Reclaimed Water during Soil Aquifer Treatment
}

\author{
Cristina Valhondo ${ }^{1,2, * \mathbb{C}}$, Jesús Carrera ${ }^{1,2}$, Lurdes Martínez-Landa ${ }^{2,3}$, Jingjing Wang ${ }^{1,2,3}$, \\ Stefano Amalfitano 4 (D), Caterina Levantesi ${ }^{4}$ and M. Silvia Diaz-Cruz ${ }^{1}$ \\ 1 Department of Environmental Chemistry, Institute of Environmental Assessment and Water \\ Research (IDAEA), Severo Ochoa Excellence Center, Spanish National Research Council (CSIC), \\ Jordi Girona 18-24, 08034 Barcelona, Spain; jesus.carrera.ramirez@gmail.com (J.C.); \\ jingjing.wang.xiang@gmail.com (J.W.); silvia.diaz@idaea.csic.es (M.S.D.-C.) \\ 2 Hydrogeology Group (UPC-CSIC), Associate Unit, Jordi Girona, 08034 Barcelona, Spain; \\ lurdesm.landa@gmail.com \\ 3 Department of Civil and Environmental Engineering, Universitat Politecnica de Catalunya (UPC), \\ Jordi Girona 1-3, 08034 Barcelona, Spain \\ 4 Water Research Institute, National Research Council, Via Salaria Km 29, 10-00015 Roma, Italy; \\ amalfitano@irsa.cnr.it (S.A.); levantesi@irsa.cnr.it (C.L.) \\ * Correspondence: cvalhondo@gmail.com
}

Received: 20 November 2019; Accepted: 27 March 2020; Published: 2 April 2020

\begin{abstract}
Managed aquifer recharge (MAR) is known to increase available water quantity and to improve water quality. However, its implementation is hindered by the concern of polluting aquifers, which might lead to onerous treatment and regulatory requirements for the source water. These requirements might make MAR unsustainable both economically and energetically. To address these concerns, we tested reactive barriers laid at the bottom of infiltration basins to enhance water quality improvement during soil passage. The goal of the barriers was to (1) provide a range of sorption sites to favor the retention of chemical contaminants and pathogens; (2) favor the development of a sequence of redox states to promote the degradation of the most recalcitrant chemical contaminants; and (3) promote the growth of plants both to reduce clogging, and to supply organic carbon and sorption sites. We summarized our experience to show that the barriers did enhance the removal of organic pollutants of concern (e.g., pharmaceuticals and personal care products). However, the barriers did not increase the removal of pathogens beyond traditional MAR systems. We reviewed the literature to suggest improvements on the design of the system to improve pathogen attenuation and to address antibiotic resistance gene transfer.
\end{abstract}

Keywords: organic amendments; managed aquifer recharge; contaminants of emerging concern (CECs); pathogens; new water challenges

\section{Introduction}

Climate change and the expansion of urban areas is a major worldwide threat to sustainable and safe drinking water supplies [1]. Managed aquifer recharge (MAR) is a technique that allows groundwater-dependent ecosystems, including rivers, to be maintained, enhanced, and/or protected with limited consumption of energy and chemicals [2,3]. MAR systems based on water filtration during soil passage have been proven to retain suspended particles and colloids, including microorganisms [4], and to favor biodegradation of chemical contaminants, resulting in significant water quality improvement [5-7]. The processes affecting pathogen transport in these aquifers are retention and inactivation, and an extensive number of factors influence them [8]. However, periodic detection of pathogens in groundwater, some with severe human health impacts [9-13], has led to strict quality 
requirements that effectively impede the use of lesser quality water for MAR. For instance, rainfall fails to meet Spanish regulations for reuse (too low $\mathrm{pH}$ and too high suspended solids), which are the regulations adopted in practice for MAR [14]. This is paradoxical because potable water treatment during the 19th century simply consisted of sand filtering to remove pathogens and resulted in a life expectancy increase of some 20 years $[15,16]$. This paradox is well reflected in the ongoing debate about quality requirements for artificial recharge. Health protection authorities recommend strict controls on the water used for MAR but, at the same time, several major cities have shown that recharge using wastewater can be safe [17]. As a result, the European Commission's Joint Research Center (JRC) failed to reach a consensus on MAR water quality recommendations [18]. The situation is inadequate. Prudence demands regulation, while fear hinders the actual implementation of MAR, which impedes the restoration of ecosystem services of groundwater-dependent water bodies.

Overcoming resistance requires the addressing of not only old problems (e.g., water scarcity, recovery of groundwater-dependent water bodies), but also emerging concerns [19]. Among these, we include chemicals of emerging concern (CECs), antibiotic-resistant bacteria (ARBs), and antibiotic resistance genes (ARGs). The term CECs encompasses a wide range of substances, including pharmaceuticals, personal care products, and nano- and micro-plastics, among others, which are characterized by their continuous release into the environment and their potential to impact aquatic ecosystems and eventually human health [20]. Several studies have demonstrated that even after extensive treatment, such as advanced oxidation processes and reverse osmosis, some recalcitrant CECs are still detectable in reclaimed water [21-23]. Until the turn of the millennium, it was unknown that these chemicals presented a hazard to the environment, as they generally occur at trace levels, and pharmaceuticals in particular were always found at concentrations far below the therapeutic doses prescribed for humans [24,25]. However, studies carried out since then have provided evidence that even sub-therapeutic concentrations of certain pharmaceuticals affect microbes, plants, fishes, and insects [26-28]. Consequently, the concentrations of CECs measured in reclaimed water can be biologically relevant or can increase to such levels in the unavoidable co-occurrence with other chemicals that may increase their biological activity [29]. Under the certainty that the reclaimed waters still contain CEC residues, the use of these waters as source waters in MAR may pose a risk to human and environmental health.

Biodegradation and sorption appear to be the main processes involved in water quality improvement during MAR, especially regarding CECs' behavior [30-32]. The biomass and biodiversity of the microbial community is relevant for CEC degradation $[33,34]$ Therefore, parameters controlling microbial community such as temperature, and the amount of organic substrate available and its quality (which controls the redox conditions), have a direct effect on biodegradation rates $[4,35,36]$. Changing parameters within an aquifer could lead to an increase in the microbial biodiversity, and a continuous source of organic substrate should allow the biomass to increase [37].

Sorption might be relevant as well since it retards contaminants [38], thus increasing the time available for the microbial community to degrade them. The discussion on whether retardation is favorable remains open. On the one hand, increasing the residence time would increase the ability of microorganisms to degrade them. On the other hand, some authors argue that contaminants are not biologically available when adsorbed, and therefore they are not potentially biodegradable [39,40].

To favor these two processes, we proposed adding a reactive barrier at the bottom of the infiltration basin in a MAR system. The barrier provides a reactive surface and diverse sorption sites, and adds organic carbon to yield a range of redox states. Ideally, this should allow diverse microbial communities to develop, thus increasing CECs' removal.

In this context, the goal of this paper was two-fold. First, we summarized what we have learned in two experiences of MAR using a reactive barrier [6,7,40,41]. Second, based on this adquired knowledgeand the results of others, we have discussed how to improve the system design and operation to enhance not only the removal of CECs but also the attenuation of pathogens, to minimize the transport of ARGs. 


\section{Materials and Methods}

\subsection{The Concept of the Reactive Barrier}

We designed a reactive barrier to be installed at the bottom of soil aquifer treatment (SAT, the specific term for intermittent infiltration of reclaimed water) infiltration basins. The barrier consisted on an organic substrate able to release dissolved organic carbon (DOC) to the infiltrated water and to provide potential sorption surfaces. The purpose of the reactive barrier is to favor biodegradation by generating a redox zonation and enhanced adsorption for the widest possible range of CECs.

Figure 1 displays redox zonation during infiltration periods in a conventional SAT system and in a system with a reactive barrier. The source water should contain a labile DOC concentration higher than 6-9 $\mathrm{mg} / \mathrm{L}$ in order to consume the oxygen and start to consume nitrate as the next electron acceptor. The implementation of the reactive barrier increases the concentration of DOC in the recharged water, so that available electron acceptors are consumed and redox zonation is developed further, reaching $\mathrm{Fe}$ - and Mn-reducing conditions, and hopefully $\mathrm{SO}_{4}$-reducing conditions. Conditions should return to aerobic during drying periods in both cases.

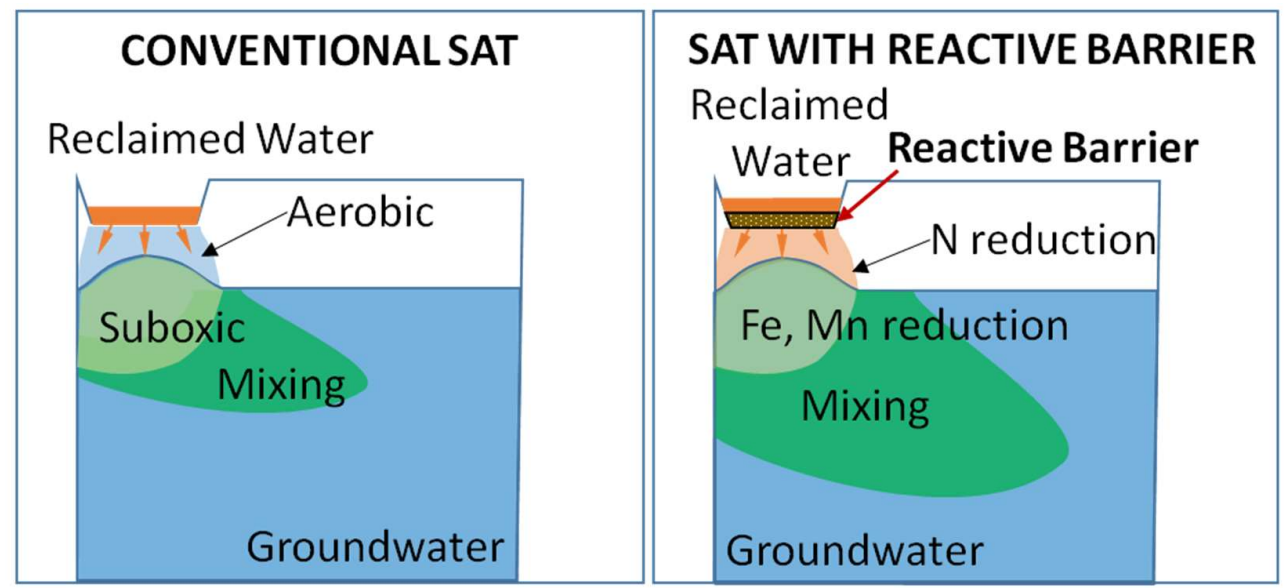

DOC Recharge Water $\sim 6-9 \mathrm{mg} / \mathrm{l}$ DOC Ground Water $\sim 2-3 \mathrm{mg} / \mathrm{l}$

Figure 1. Schematic description of redox zonation during infiltration without and with a reactive barrier. The barrier adds dissolved organic carbon (DOC) to the recharge water, thus promoting highly reducing conditions. Ideally, the vadose zone becomes aerobic during drying periods in both cases.

This approach was tested at two sites and based on two organic substrates as organic carbon source, i.e., compost and woodchips. The first site was a pilot-scale MAR system located at Sant Vicenç dels Horts (close to Barcelona, Spain) where a reactive barrier based on compost was installed. The system operated with the barrier for four consecutive years. The second site consisted of six MAR systems with small variations in the configuration, located in Palamós (close to Gerona, Spain). One of the systems, the reference one, operated without a reactive barrier, four systems operated with reactive barriers based on compost, and the remaining system operated with a reactive barrier based on woodchips. To date, it appears that the implementation of these barriers has favored the infiltration capacity. The characteristics of each site and the performance of the tested reactive barriers were described in previous publications $[6,7,41,42]$ and are summarized later.

Compost and woodchips were selected as organic substrates due to their capability to release DOC, their low cost, and the ease of their handling and transportation. The amount of DOC released by the organic substrate is expected to decrease with time (or with the volume of water infiltrated), 
but it may be compensated by the release from biomass growing in the basin, including plant roots. Still, after a period of operation, the barrier may have to be replaced.

\subsection{Site Description}

\subsubsection{Sant Vicenç Dels Horts}

The Sant Vicenç site is a complex of two basins (settlement and recharge, each $\sim 5000 \mathrm{~m}^{2}$ ) constructed at the side of the Llobregat River, some $15 \mathrm{~km}$ upstream of Barcelona (Figure 2A). The MAR system was constructed over the lower Llobregat valley sedimentary aquifer, formed mainly by gravels, sand, and a small fraction of clay [43]. The saturated aquifer thickness and vadose zone ranged from 12 to $14 \mathrm{~m}$, and from 5 to $9 \mathrm{~m}$, respectively, during the recharge experience (Figure 2C).
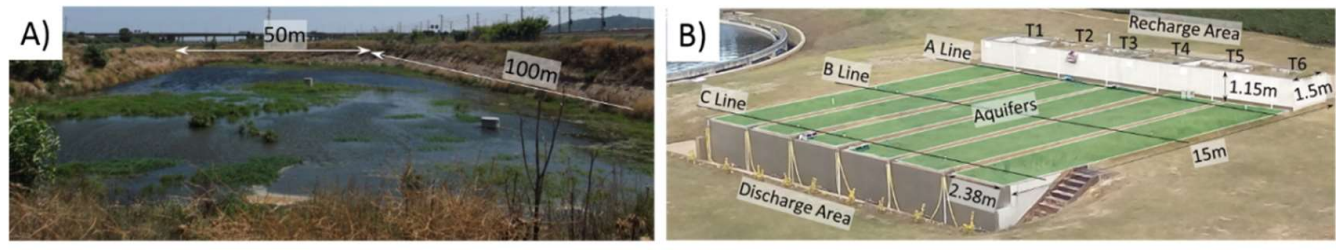

C)

D)

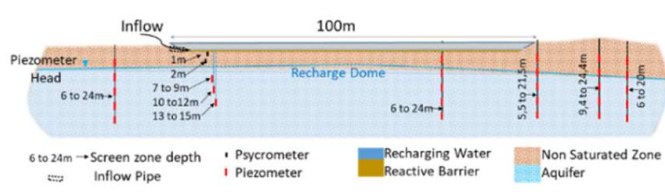

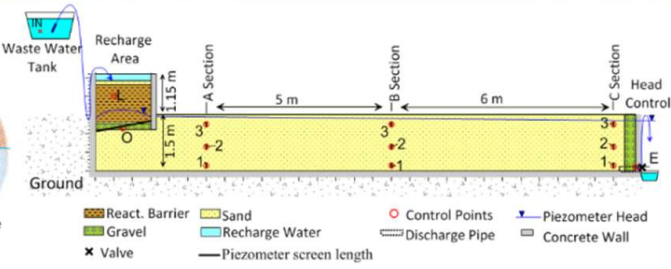

Figure 2. (A) Sant Vicenç dels Horts infiltration basin, and (C) the cross-section with the monitoring points and their screened sections; (B) six Palamós replicate MAR systems named T1 to T6, and (D) the cross-section of one generic replicate. Flow direction is from left to right in both cross-sections.

The MAR system was fed with the Llobregat River water, which is heavily impacted by wastewater treatment plants' (WWTPs') effluents [44]. The river water was diverted to the settlement basin, where it remained for 2 to 4 days. From there, water flowed to the recharge basin. Flow rate was measured hourly into the connecting pipe. The average infiltration rate was $1 \mathrm{~m} / \mathrm{d}$.

We installed a $65 \mathrm{~cm}$ thick reactive barrier on the bottom of the infiltration basin. This barrier consisted of vegetal compost and aquifer sediments in equal volumetric portions and a small quantity of clay and iron oxide. The role of the vegetable compost was to release degradable organic matter to the infiltrating water to favor changes in redox conditions underneath the basin, promoting microbiological diversity to enhance the removal of chemical contaminants $[6,7,37,45]$, and to provide surfaces for neutral organic compound adsorption. Clay increased the sorption of cationic compounds and iron oxide facilitated the sorption of the anionic ones.

\subsubsection{Palamós Site}

The pilot MAR system was constructed in a municipal WWTP facility on the northeastern Spanish Mediterranean coast. This facility collects wastewater from several municipalities. The population served increases to include some 90,000 inhabitants during the summer, reaching the maximum treatment capacity of the plant. As a consequence, effluent water quality varies throughout the year.

We constructed six pilot recharge systems $\left(15 \times 15 \mathrm{~m}^{2}\right.$ excavated structures, divided into six $2.38 \times 15$ m channels; Figure $2 \mathrm{~B}$ ), to test the effect of the reactive barrier's composition and the role of plants on the fate of CECs and pathogens. The system was fed with the secondary treatment effluent of the WWTP, which infiltrated from the basin through the barrier and further flowed along the $15 \mathrm{~m}$ simulated aquifer, to finally discharge at the base of the $1.5 \mathrm{~m}$ thick aquifer. Indeed, the pilot MAR operated as a tertiary treatment (Figure 2D). In this case, two organic carbon sources were tested: 
compost and wood chips. We assessed their performance by comparing the removal of more than $50 \mathrm{CEC}$ and pathogen indicators to that of a reference system (infiltration without reactive barrier).

\subsection{Analytical Methods}

Pressure, temperature, and electrical conductivity were continuously recorded using conductivity, temperature and depth submersible dataloggers (CTD-Divers, Schlumberger water services, Delft, The Netherlands) in the source water and several monitoring points at San Vicenç dels Horts and Palamós sites (Figure 2C). Additionally, samples for chemical analysis were collected during several recharge events in both sites.

Target CECs were selected based on the frequency of their detection in the aquatic environment, and since the analytical methodology for each site was different, the final list of CECs analyzed in each case was defined according to the methodology requirements and the source water type (urban, hospital effluents, agricultural, or industrial).

At Sant Vicenç dels Horts, 51 CECs were analyzed in the collected samples following the method described by Nödler et al. [46] (Table S1). Briefly, the samples were allowed to settle overnight at $4{ }^{\circ} \mathrm{C}$ and the supernatant was recovered. A $500 \mathrm{~mL}$ aliquot of the supernatant was spiked with $10 \mu \mathrm{L}$ of an internal standard solution and with $5 \mathrm{~mL}$ of a buffer solution before solid-phase extraction (SPE). The extraction and purification was performed using OASIS HLB $(6 \mathrm{~mL}, 500 \mathrm{mg}$; Waters, Eschborn, Germany) cartridges. The analytes were eluted from the cartridges, and the extracts were evaporated with a stream of nitrogen and reconstituted with ammonium acetate solution before its transference to an auto-sampler LC-vial. The analyses were performed by high-performance liquid chromatography tandem-mass spectrometry (HPLC-MS/MS, Varian Inc., Palo Alto, CA, USA).

At the Palamós site, 58 CECs were determined by online solid-phase extraction coupled to high-performance liquid chromatography-tandem mass spectrometry (online-SPE-HPLC-MS/MS) in accordance with Gago-Ferrero et al. [47] (Table S2). In this method, water samples previously spiked with an isotopically labeled surrogate standard solution were isolated, pre-concentrated, and purified using an automated Symbiosis ${ }^{\mathrm{TM}}$ Pico online SPE-(Spark Holland; Emmen, the Netherlands). The online SPE of all samples, calibration standard solutions, and methodological blanks were performed by loading $5 \mathrm{~mL}$ of the water samples through PLRP-s cartridges. The trapped compounds were eluted from the cartridge to the HPLC column by the chromatographic mobile phase. The chromatographic separation was achieved with a HibarPurospher ${ }^{\circledR}$ STAR ${ }^{\circledR}$ HR R-18 ec. $(50 \mathrm{~mm} \times 2.0 \mathrm{~mm}, 5 \mu \mathrm{m})$ column from Merck using a mobile phase consisting of HPLC-grade water and acetonitrile, both with $0.1 \%$ formic acid for positive electrospray ionization, and with $5 \mathrm{mM}$ ammonium acetate buffer ( $\mathrm{pH}$ 6.8) for the negative ionization mode. MS/MS detection was performed on a $4000 \mathrm{Q}$ TRAP ${ }^{\mathrm{TM}} \mathrm{MS} / \mathrm{MS}$ hybrid mass spectrometer from Applied Biosystems-Sciex (Foster City, CA, USA). Selected reaction monitoring (SRM) mode was applied for improved selectivity and sensitivity. Four identification points were considered, in compliance with the European Council Directive 2002/657/EC [48].

Additionally, a microbiological analysis was carried out at the Palamós site. Gram-positive and Gram-negative fecal bacteria indicator analysis was done via most probable number (MPN) detection tests following manufacturer's instructions (Colilert IDEXX, US). The log removal values were calculated considering the average of total coliforms and Escherichia coli concentrations in the source water, in the monitoring point immediately below the reactive barrier (O-points), and effluents (E-points) for each MAR system of Palamós site (Figure 2D). We analyzed also other substances, namely DOC, cations and anions, but they are out of the focus of the present study.

\subsection{Assesing the Reactive Barrier Efficiency}

We estimated first-order degradation rates $(\lambda)$ and retardation coefficient (R) for 10 CECs at Sant Vicenç dels Horts site [41,49] and compared them with those reported in the literature from other experiments. While $\lambda \mathrm{s}$ can be highly uncertain, they can be considered "relative measures for comparison" of results [50]. To this end, we measured pressure, electrical conductivity, and temperature 
at different distances from the infiltration basin. We also performed a pulse injection tracer test to obtain the residence time distribution of the recharged water at six monitoring points. The heads and breakthrough curves were used to estimate the flow and conservative transport parameters of the aquifer using a quasi-3D numerical model [49]. The model was built using the finite element code Transdens [51-53]. Secondly, CEC concentrations measured in the source water and nine monitoring points were used to estimate $\lambda$ and $\mathrm{R}$ (in three and two defined subdomains, respectively) for 10 CECs $[41,49]$. The subdomains for $\lambda$ estimation were BARR (reactive barrier), UZ (unsaturated zone), and AQF (aquifer). The subdomains for R estimation were BAR (reactive barrier) and UZ+AQF (unsaturated zone and aquifer). Pathogen indicators were not analyzed at the Sant Vicenç dels Horts site.

At the Palamós site, we compared the reduction in the concentration of 58 CECs, classified into four groups namely UV filters, paraben preservatives, pharmaceuticals, and total contaminants' load Table S2). Besides, the pathogen indicators (total coliforms and E. coli) were also measured along the reference system and compared to those obtained for the systems operating with the two reactive barriers to assess the efficiencies of these designs.

\section{Results and Discussion}

\subsection{CECs Behavior}

Figure 3 shows the comparison among the estimated degradation rates, $\lambda(\mathrm{A})$, and retardation coefficients, R (B), at Sant Vicenç dels Horts and those reported from other studies carried out both in laboratory experiments and at field sites [54-62]. Considering the typical maximum duration for columns (1-2 years) and field experiments (10-20 years), the minimum value for $\lambda$ was allowed to be $10^{-3}$, and $10^{-4} \mathrm{~d}^{-1}$, respectively, following the approach from Greskowiak et al. [63].

Estimated $\lambda s$ for the Sant Vicenç dels Horts site, operating with the reactive barrier, were similar to or higher than those reported in the literature. Indeed, the $\lambda$ s estimated for the reactive barrier subdomain (BARR) tended to be much larger than literature values, whereas the $\lambda$ s estimated for the aquifer domain (AQU) were comparable, suggesting the proper performance of the reactive barrier. Estimated Rs were also much higher than literature values for the barrier (BARR) and comparable for the aquifer (UZ + AQU). At this site, we did not have the opportunity to operate the system with and without reactive barrier simultaneously while keeping the remaining variables identical to assess the performance of the barrier. However, the proper assessment of the barriers' efficiency was performed at the Palamós site. There, we estimated removal efficiencies of the analyzed CECs for the reference system (T2) and the systems operating with the two reactive barriers (T4 and T5). For the sake of clarity, we compiled the information on the analyzed CECs grouped into four categories, as aforementioned i.e., UV filters ( $\Sigma U V F)$, paraben preservatives ( $\Sigma$ PBs), pharmaceuticals ( $\Sigma$ PhAC), and total load of the analyzed CECs ( $\Sigma$ TOTAL) (Table S2).

Figure 4 displays the removal efficiencies for the target contaminants (Table S2), estimated for the reference system (T2) and the systems operating with reactive barriers (T4 and T5) in two recharge periods, i.e., January and March 2018. Overall, significant removal, from $40 \%$ to $100 \%$, was observed in all three systems, supporting the robustness of MAR in improving recharged water quality. Additionally, the systems operating with the reactive barrier performed equally well to or better than the reference system, indicating that the reactive barrier was successful at enhancing CEC removal. However, differences between the two barrier types' efficiencies were compound-dependent. This finding was in agreement with the results reported from a laboratory study carried out by Bertelkamp et al. [64], who investigated the sorption and biodegradation behavior of 14 CECs in soil columns under oxic conditions. They concluded that the presence of ethers and carbonyl groups increased biodegradability, whereas ring structures, amines, aliphatic ethers, and sulfides hindered degradation [64]. 

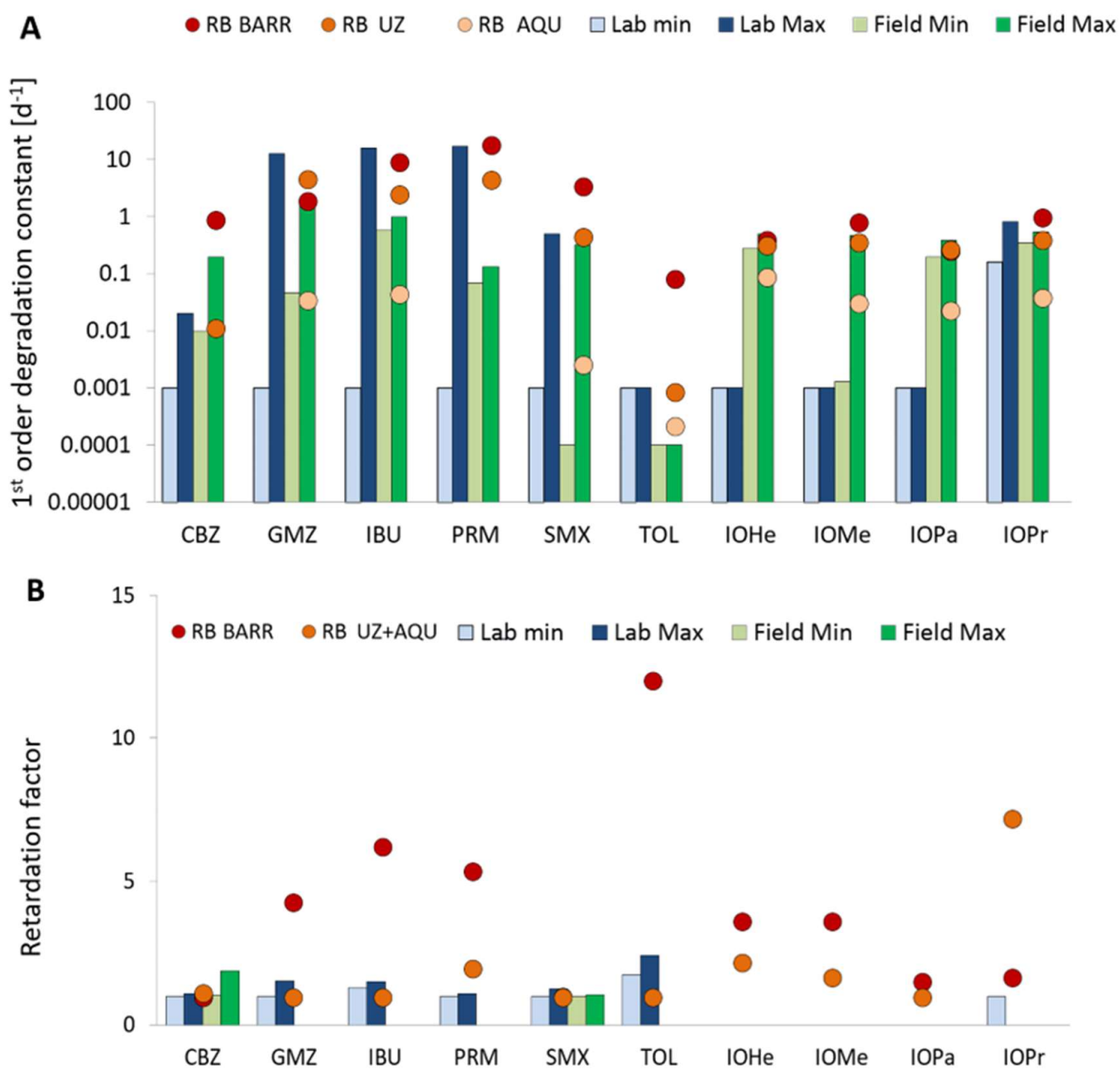

Figure 3. (A) First-order degradation rates $(\lambda)$ (estimated for the three domains) and (B) retention factors (R) (estimated for two domains) at the Sant Vicenç dels Horts site for carbamazepine (CBZ), gemfibrozil (GMZ), ibuprofen (IBU), primidone (PRM), sulfamethoxazole (SMX), tolyltriazole (TOL), iohexol (IOHe), iomeprol (IOMe), iopamidole (IOPa), and iopromide (IOPr) and comparison with data from the literature obtained in field and laboratory column experiments.

A

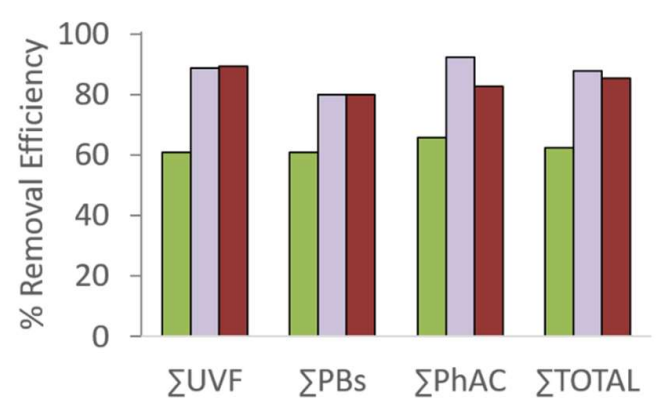

B

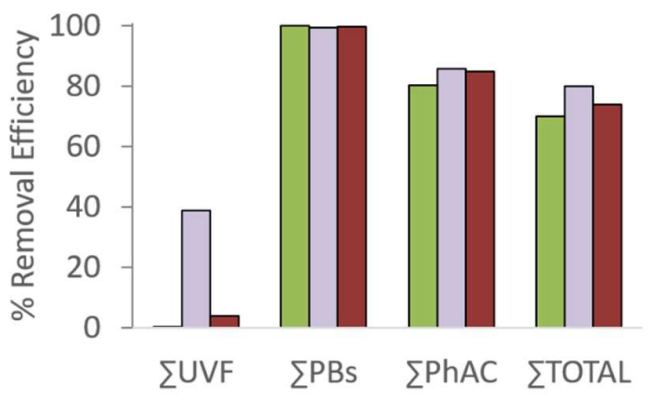

Figure 4. Removal efficiencies for organic UV filters ( $\Sigma \mathrm{UVF})$, paraben preservatives $(\Sigma P B)$, pharmaceuticals ( $\mathrm{PhAC}$ ), and total CECs ( $\mathrm{TTOTAL}$ ) estimated at the effluent of the reference system (T2), the system operating with the reactive barrier based on compost (T4), and the system operating with the barrier based on woodchips (T5) during (A) January 2018 and (B) March 2018 recharge episodes. 
Our results demonstrate that a reactive barrier improved the removal of CECs, but other options are possible. Several authors have reported that oxic conditions and low biodegradable dissolved organic carbon (BDOC) favor CECs' degradation [57,65], whereas others suggest that anoxic conditions favor the degradation of a broader range of CECs [6,7,66-68]. Regnery et al. [69] proposed a method to reduce BDOC while boosting aerobic conditions during MAR by coupling two MAR systems, riverbank filtration followed by an aeration step prior to soil aquifer treatment. The goal was to reduce the BDOC during the riverbank filtration and to induce aerobic conditions with the aeration, providing oxic and low-BDOC conditions to the second MAR system $[69,70]$. In our experiences, we achieved reducing conditions during the recharge, assuming that aerobic conditions would be reached in the aquifer after recharged water mixed with native groundwater. This approach reduces the demands on the technique, since only one MAR system is needed. The issue is not settled, but it is clear that the optimal design of a MAR system is driven by several factors, including the water source, the hydrological characteristics of the aquifer, the geographical situation, and land availability, among others. Therefore, it is desirable to have a large set of MAR configuration options to select the most suitable for each particular case.

\subsection{Pathogen Removal}

The barriers' efficiency at reducing total coliforms and E. coli at Palamós during the recharge episode in March 2018 is shown in Figure 5. We compared their concentrations in the source water (INF) to those immediately below the vadose zone $(\mathrm{O})$ and in the effluent $(\mathrm{E})$ for the reference system (T2) and the systems operating with the reactive barriers based on compost and woodchips (T4 and T5, respectively). Figure 5 displays reductions between 2.5 and $5 \log$ units for both, total coliforms and Escherichia coli. (E. coli). Similar results were observed during other recharge episodes. Overall, few or no differences among the systems were observed.
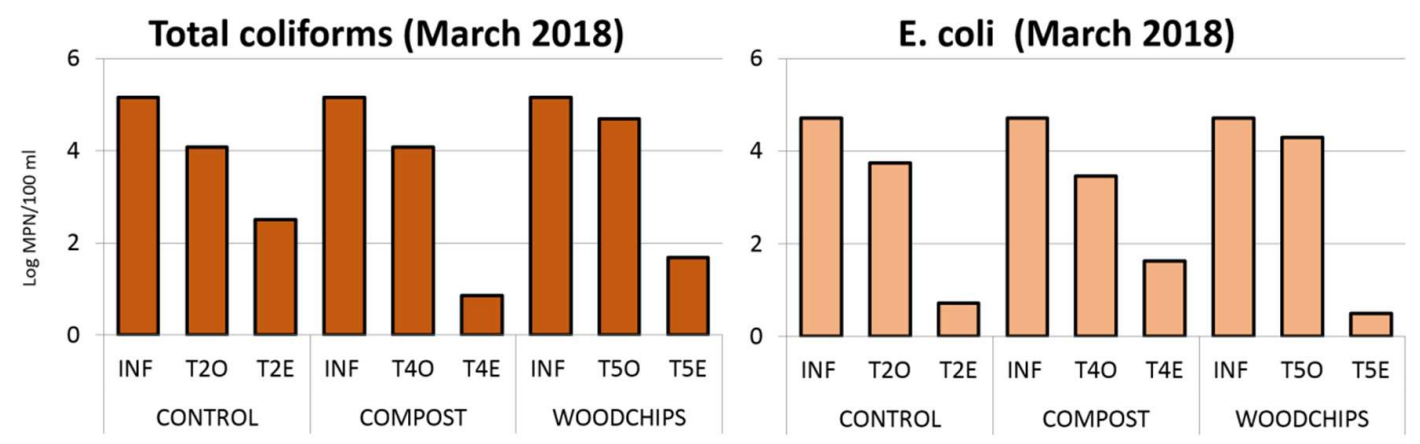

Figure 5. Concentrations (log MPN/100 mL) of total coliforms and Escherichia coli (E. coli)measured at the inflow (INF), immediately below the vadose zone (O-points), and effluent (E-points) of the reference system (T2, control) and the systems operating with reactive barriers based on compost (T4) and woodchips (T5) during the March 2018 recharge episode.

These results suggest that the barrier did not increase the attenuation of pathogens beyond traditional MAR systems, and, therefore, the system needs to be improved. Unfortunately, pathogen removal has traditionally been taken for granted in aquifers and, as a consequence, conceptual understanding is limited so far. Still, much research is available in the sand filtration literature, both rapid and slow sand filtration (more relevant for MAR) [71,72]. Materials other than sand have also been studied. Perez-Mercado et al. [73] explored the performance of biochar in reducing bacterial indicators from wastewater, with varying success.

While the extent of the supporting evidence is highly variable, the consensus is that pathogen fate is governed by two processes: retention and inactivation.

Retention refers to the immobilization of pathogens by straining or adsorption [8]. Straining refers to physical blocking of particles at small pores, and it is often assumed to occur at pores smaller than the bacteria size [74]. This contradicts what is known about colloidal straining, where filtration is 
largely caused by the lumping of particles, but it is hard to falsify. Adsorption refers to the retention of particles by electrostatic forces (actually, the set of mechanisms is much broader, ranging from diffusion into immobile water pores to the formation of surface complexes). Adsorption is usually explained using the double-, sometimes triple-layer theory.

Regardless of the actual mechanism (for quantification and upscaling purposes, identifying the retention mechanism is important), several factors affect pathogen retention, including size and accessible surface (in practice, they are hard to separate, since a small grain size leads to a high specific surface), hydraulic gradient (rather than velocity), $\mathrm{pH}$ (which controls the surface charge of both microorganisms and mineral surfaces), temperature, ionic strength (which affects surface potential, so that both increased and reduced retentions have been reported), and biofilm [75]. While a unified approach needs to be synthesized from the extensive literature on this topic, it is clear that a broad range of surface types and chemical states (ionic strength and $\mathrm{pH}$ appear to be the most controlling parameters) favor retention [76].

Inactivation is more difficult to ascertain. Pathogens tend to die outside the human body, which provides optimal conditions for their survival. The question, therefore, is how long it takes and whether it can be confirmed. Inactivation may occur in the liquid phase or, after adsorption, in the solid phase. Numerous factors contribute, including $\mathrm{pH}$ (in general, acidic conditions facilitate removal), temperature (survival has been observed to decrease with increasing temperature), and the presence of predators [77]. The conclusion from these studies is that most pathogens die off after a few weeks of residence in the soil. However, a few form spores or adopt spore-like forms that become inactive under unfavorable conditions but "resuscitate" when these conditions are favorable. For these, ascertaining elimination at the solid phase is critical [78].

It is precisely this variability in responses that underscores the need to observe a range of microorganisms. Given the impossibility to analyze all of them, it is common to use "indicator microorganisms" (bacteriophages, E. coli, Cryptosporidium, Clostridium).

The presence of metals favors inactivation. Urfer [79] showed that the addition of aluminum to (slow) sand filters enhanced the removal of bacteria. This is relevant because reclaimed water is often rich in aluminum (generally used for promoting flocculation during primary wastewater treatment). This aluminum will not precipitate as bauxite, but as gibbsite $\left[\mathrm{Al}(\mathrm{OH})_{3}\right]$ at neutral $\mathrm{pH}$. Still, its trivalent state should favor retention and would explain why biofilm ageing increases pathogen retention. Park et al. [76] conducted column experiments with Cryptosporidium parvum oocysts (a frequent indicator microorganism) and found that retention was greatly enhanced by the presence of iron coatings on the sand medium and that suspended illite clay drastically enhanced oocyst deposition. Increasing ionic strength (up to a certain value) and decreasing $\mathrm{pH}$ also enhanced attachment efficiency.

Pathogenic behavior has been studied in numerous artificial recharge sites. Weiss et al. [80] calculated reductions from 2 to $4 \log$ units for aerobic spores and $5.5 \log$ units for total coliforms after travel distances between 24 and $177 \mathrm{~m}$ in three different riverbank filtration areas in the USA.

Bekele et al. [81] conducted a 39 month study on changes in water quality during infiltration through an unsaturated zone of $9 \mathrm{~m}$ and concluded that the elimination of microbial species was efficient: it detected adenovirus in only $6 \%$ and enteric viruses in $4 \%$ of the samples after 4.2 days.

Betancourt et al. [82] evaluated the elimination of enteric viruses in three artificial recharge facilities in the USA: one induced recharge (Colorado), an infiltration basin in Tucson, and another one in California. They concluded that enteric viruses group was below the bioanalytical method limit of detection after 5 days of transit time, and that residence time played a key role in the elimination of pathogens. The only infectious virus detected in the study was a reovirus. As it is difficult to associate reoviruses with a specific disease, they have not been paid much attention. However, they were found at higher concentrations than enteroviruses in treated and untreated wastewater, proving to be more resistant to UV disinfection than enteroviruses. Moreover, it appears that they also survive in water for long periods of time. According to these outcomes, reoviruses should be monitored in MAR system studies. 
Elkayam et al. [83] studied several indicators at Shafdan (Israel), which recharges secondary effluent from a WWTP through 54 infiltration basins, covering an area of 270 ha in the coastal aquifer of Israel. The aquifer is formed of calcareous sandstones with intercalations of conglomerates, silts, and clay layers. Aquifer thickness is $180-200 \mathrm{~m}$. The unsaturated area under the basins is $30-40 \mathrm{~m}$ deep. The wells are placed in two rings around the basins. The first ring extracts only recharged water from the rafts, whereas the second extracts also between $15 \%$ and $30 \%$ of water from the aquifer. The system has been operating on a large scale for more than 30 years. The study focused on indicators of bacteria, pathogenic viruses, coliphages, microbial source-tracking indicators (MST), and ARGs. The results showed a complete elimination of pathogenic viruses (enteroviruses, adenoviruses, noroviruses, parechoviruses), coliphages, and indicators of total and fecal bacteria and coliforms, fecal streptococcus, and bacteroides (MST) in the unsaturated area under the rafts. ARGs were detected in several wells, but they were also found in wells not impacted by the effluent, suggesting that these genes were related to the native microbial communities of the aquifer.

Beyond the actual mechanism controlling the fate of pathogens, it is important to take into account that (1) the soil is a living organism in itself, and (2) a broad range of pathogens, with different properties, may be present in treated wastewater or other source waters. The former implies that the soil system will be sensitive to external perturbations and its behavior will evolve in time. This, together with the specificities of every microorganism type, may explain the broad range of often contradictory sets of results reported in the literature.

The role of redox state has hardly been analyzed [84], which may reflect that most work is motivated by sand filters. Since we argue that a sequence of redox states improves the removal of CECs, it would also be desirable to understand the effect of redox state on the fate of pathogens. However, the indirect impact of redox variability becomes apparent. Bringing the water back into aerobic conditions favors the oxidation of iron (ferrous iron is mobile, while ferric iron tends to precipitate as goethite or its precursors). The positively charged surfaces of ferric oxides should retain pathogens that are mobile in other environments [84].

Thick unsaturated zones consistently lead to excellent removal rates of pathogens, and specifically viruses. While we attribute this success to air-water interfaces, which tend to retain colloids, other factors may be at play. The thickness of the unsaturated zone can only be controlled by pumping or, at the design stage, by site selection. Unfortunately, we did not have a thick unsaturated zone at our Palamós pilot site.

\subsection{Antibiotic-Resistant Bacteria (ARB) and Antibiotic-Resistant Genes (ARGs)}

Antibiotic resistance is a growing issue. Resistance is one of a number of consequences of the misuse and overuse of human and veterinary antibiotic drugs [85-88]. Antibiotics are substances that prevent the growth of bacteria. The term encompasses a wide range of pharmaceuticals with quite different physicochemical properties that are used in the treatment of bacterial infections, and also as prophylaxis for cattle and poultry. However, over the past decade, bacteria have been found to resist the drugs developed to suppress their growth and biological activity. In other words, bacterial strains are developing antibiotic resistance.

According to a recent report on the occurrence of antibiotic resistance in the USA [89], almost 3 million antibiotic-resistant infections are diagnosed every year in the USA, resulting in the deaths of more than 35,000 people. Globally, 10 million deaths per year caused by antibiotic-resistant bacterial infections are expected by 2050. Antibiotic-resistant bacteria, along with their resistance genes, are spread globally among foodstuffs, animals, plants, people, and the environment [90]. In this context, the World Health Organization (WHO) proposed a holistic action plan on microbial resistance involving humans and the environment [91], and the European Commission launched "One Health" as the European Action Plan to fight against antimicrobial resistance [92]. Additionally, the Watchlist for European Union monitoring defined in the Decisions 2018/840/EU (5 June 2018) included five antibiotics to be used to gather occurrence data to estimate the associated environmental risk of certain potentially hazardous compounds [93]. 
One of the reasons why ARGs cause great concern is because they are related to mobile genetic elements, and can therefore be easily transferred among microorganisms by horizontal gene transfer. This transfer can occur from bacteria, phages, free DNA, and dead cells to living cells [94].

WWTPs, in particular those treating urban sewage, have been recognized as one of the major receptors/sources of antibiotic resistance in the environment [88]. Even worse, ARGs may be enhanced in WWTPs [88]. The relationship between residual antibiotics in WWTPs and ARGs remains unclear. According to some studies, the presence of antibiotic residues during wastewater treatment may influence antibiotic resistance $[87,95,96]$. In contrast, other authors have pointed out that no correlation exists between the load of antibiotic residues in WWTPs and ARG abundance [97]. Nevertheless, a strong relationship between clinical and environmental antibiotic resistance has been reported. Temperature and humidity have been identified as two key factors controlling antibiotic resistance.

Since WWTPs are implicated as hotspots for the dissemination of antibiotic resistance into the environment and secondary effluents display higher relative abundance than the influents [98], it is important to assess whether ARGs could be reduced during soil aquifer treatment. Lack of a solid conceptual model for the fate of ARGs makes any proposal highly conjectural. However, some pieces of side evidence appear hopeful. The generation of anaerobic areas should help because the activity of microorganisms is reduced and the transfer of ARG is inhibited [99]. The presence of plants has proven efficient at removing ARGs in constructed wetlands [100]. The plant species selection deserves further research. In a recent study, the addition of biochar to soil resulted in notable changes in the microbial community, and these changes were different depending on the type of biochar used [101]. Changes in bacterial phylogenetic compositions can result in a change of ARGs. Therefore, the use of biochar as a component of reactive barriers might reduce ARGs. Nanotechnology may also be tested in MAR systems by including new nanomaterials in the infiltration pathway. To date, a few studies have pointed out the capability of selected nanomaterials to eliminate both ARB and ARGs [102].

\subsection{Public Acceptance of MAR}

A positive perception of MAR by the public is essential for its smooth implementation as a feasible and effective solution to increase water resources. The results of a public consultation about the use of treated wastewater in MAR operations were published recently [103]. Among the opposed respondents, the major concern was the lack of confidence in the wastewater treatment effectiveness before recharge. It is feared that if chemical and biological contaminants are recalcitrant to the treatments, recharge with WWTP effluents will lead to worsening groundwater quality. This kind of concern has led to broad negative public opinion on water reuse in general [104]. Negative perceptions may lead to failure [105-107].

In this regard, the implementation of operational strategies or designs to increase pathogen attenuation, chemical contaminant removal, and ARB and ARGs mitigation in MAR systems would facilitate public acceptance. If pilot studies are undertaken and results are successful, the MAR benefits supported by reliable scientific information should be stated and reasonably presented to the public. It is likely that the availability and understanding of this information will facilitate their positive perception and ultimately achieve public support.

Our concern, however, is that this may not suffice in times of "post-truth" and "fake news". Traditional approaches are needed: working with community organizations, promoting positive local media coverage of projects involving MAR, giving messages in clear non-technical language emphasizing its benefits and safety, offering public visits to the facilities, etc. Additional avenues of action that are specific to MAR include:

1. MAR (re)naturalizes water in that water quality improvement processes make it hard to distinguish from natural water;

2. Infiltration basins are beautiful, especially when covered with vegetation (Figure 2). This, together with the relatively large surface area of infiltration basins, suggests integrating them as part of landscape and territorial planning. 


\section{Conclusions and Current/Future Challenges in MAR}

Our work supports the extensive literature body on water quality improvement during soil passage. Specifically, adding a reactive barrier improved the removal of chemical contaminants. Still, pathogen attenuation is significant (2-5 log units in our case), but was not particularly improved by the addition of the reactive barrier. Therefore, further improvement in the design of the reactive barriers and the operation of the system is needed.

We have discussed several options to enhance the degradation of recalcitrant chemical contaminants and the mitigation of pathogens. These include new compositions of the reactive barrier to broaden the types of sorption surfaces (biochar, zeolite, etc.), addition of metals to promote pathogen inactivation, implementation of thicker unsaturated zones to increase pathogen retention, and changes in the system operation to favor ferric oxide precipitation to create positively charged surfaces for further pathogen attenuation. We will test these approaches in the coming years at the Palamós pilot site and will assess the performance of the optimized system through the monitoring not only of CECs and pathogens, but also the development of antibiotic resistance, a serious emerging concern nowadays.

Public support must be achieved for the broad success of MAR. In the current context of climate change, where events of water scarcity and floods are occurring daily, improving water quality and increasing its quantity deserve determined action.

Supplementary Materials: Supplementary Materials are available online at http://www.mdpi.com/2073-4441/12/ 4/1012/s1.

Author Contributions: Conceptualization, C.V., J.C., L.M.-L., and M.S.D.-C.; Investigation and Methodology, C.V., L.M.-L., S.A., C.L., J.W. and M.S.D.-C.; Supervision, J.C. and M.S.D.-C. Writing-original draft, C.V., J.C. and M.S.D.-C.; Writing-review and editing, C.V., J.C., L.M.-L., S.A., C.L., J.W., and M.S.D.-C. All authors have read and agreed to the published version of the manuscript.

Funding: This research was funded by the Spanish Ministry of Science and Innovation CEX2018-000794-S), Water JPI (MARadentro-PCI2019-103603) and Catalan Water Agency (RESTORA-CA210/18/00040).

Acknowledgments: The authors acknowledge the Consorci Costa Brava for its constant support and the staff working at Palamós site for their unconditional help.

Conflicts of Interest: The authors declare no conflict of interest.

\section{References}

1. Wheeler, T.; Von Braun, J. Climate change impacts on global food security. Science 2013, 341, 508-513. [CrossRef] [PubMed]

2. Bouwer, H. Artificial recharge of groundwater: Hydrogeology and engineering. Hydrogeol. J. 2002, 10, 121-142. [CrossRef]

3. Dillon, P.; Stuyfzand, P.; Grischek, T.; Lluria, M.; Pyne, R.D.G.; Jain, R.C.; Bear, J.; Schwarz, J.; Wang, W.; Fernandez, E.; et al. Sixty years of global progress in managed aquifer recharge. Hydrogeology 2018. [CrossRef]

4. Rauch-Williams, T.; Hoppe-Jones, C.; Drewes, J.E. The role of organic matter in the removal of emerging trace organic chemicals during managed aquifer recharge. Water Res. 2010, 44, 449-460. [CrossRef] [PubMed]

5. Patterson, B.M.; Shackleton, M.; Furness, A.J.; Bekele, E.; Pearce, J.; Linge, K.L.; Busetti, F.; Spadek, T.; Toze, S. Behaviour and fate of nine recycled water trace organics during managed aquifer recharge in an aerobic aquifer. J. Contam. Hydrol. 2011, 122, 53-62. [CrossRef] [PubMed]

6. Valhondo, C.; Carrera, J.; Ayora, C.; Barbieri, M.; Nödler, K.; Licha, T.; Huerta, M. Behavior of nine selected emerging trace organic contaminants in an artificial recharge system supplemented with a reactive barrier. Environ. Sci. Pollut. Res 2014, 1-12. [CrossRef]

7. Valhondo, C.; Carrera, J.; Ayora, C.; Tubau, I.; Martinez-Landa, L.; Nödler, K.; Licha, T. Characterizing redox conditions and monitoring attenuation of selected pharmaceuticals during artificial recharge through a reactive layer. Sci. Total Environ. 2015, 512, 240-250. [CrossRef]

8. Stevik, T.K.; Aa, K.; Ausland, G.; Hanssen, J.F. Retention and removal of pathogenic bacteria in wastewater percolating through porous media: A review. Water Res. 2004, 38, 1355-1367. [CrossRef] 
9. Hrudey, S.E.; Payment, P.; Huck, P.M.; Gillham, R.W.; Hrudey, E.J. A fatal waterborne disease epidemic in Walkerton, Ontario: Comparison with other waterborne outbreaks in the developed world. Water Sci. Technol. 2003, 47, 7-14. [CrossRef]

10. Craun, M.F.; Craun, G.F.; Calderon, R.L.; Beach, M.J. Waterborne outbreaks reported in the United States. J. Water Health 2006, 4, 19-30. [CrossRef]

11. Pedley, S.; Howard, G. The public health implications of microbiological contamination of groundwater. Q. J. Eng. Geol. 1997, 30, 179-188. [CrossRef]

12. Pandey, P.K.; Kass, P.H.; Soupir, M.L.; Biswas, S.; Singh, V.P. Contamination of water resources by pathogenic bacteria. AMB Express 2014, 4, 1-16. [CrossRef] [PubMed]

13. Marzouk, Y.; Goyal, S.M.; Gerba, C.P. Relationship of viruses and indicator bacteria in water and wastewater of Israel. Water Res. 1980, 14, 1585-1590. [CrossRef]

14. Boe, M.; Real, D. De 7 de diciembre, por el que se establece el régimen jurídico de la reutilización de las aguas depuradas. boe 7 DICIEMBRE 2007, 1620, 50639-50661.

15. Preston, S.H.; Van De Walle, E. Urban French Mortality in the Nineteenth Century; Taylor \& Francis Ltd.: Abingdon, UK, 2016.

16. Preston, S.H.; Van De Walle, E. Urban French Mortality in the Nineteenth Century. Popul. Stud. 1978, 32, 275-297. [CrossRef]

17. Asano, T.; Cotruvo, J.A. Groundwater recharge with reclaimed municipal wastewater: Health and regulatory considerations. Water Res. 2004, 38, 1941-1951. [CrossRef] [PubMed]

18. Alcalde-Sanz, L.; Gawlik, B.M. Minimum Quality Requirements for Water Reuse in Agricultural Irrigation and Aquifer Recharge. Available online: https://publications.jrc.ec.europa.eu/repository/bitstream/JRC109291/ jrc109291_online_08022018.pdf (accessed on 1 April 2020).

19. Dillon, P. Future management of aquifer recharge. Hydrogeol. J. 2015, 13, 313-316. [CrossRef]

20. EPA Contaminants of Emerging Concern including Pharmaceuticals and Personal Care Products. Available online: https://www.epa.gov/wqc/contaminants-emerging-concern-including-pharmaceuticals-andpersonalcare-products (accessed on 19 January 2019).

21. Kinney, C.A.; Furlong, E.T.; Werner, S.L.; Cahill, J.D. Presence and distribution of wastewater-derived pharmaceuticals in soil irrigated with reclaimed water. Environ. Toxicol. Chem. 2006, 25, 317-326. [CrossRef]

22. Urtiaga, A.M.; Pérez, G.; Ibáñez, R.; Ortiz, I. Removal of pharmaceuticals from a WWTP secondary effluent by ultrafiltration/reverse osmosis followed by electrochemical oxidation of the RO concentrate. Desalination 2013, 331, 26-34. [CrossRef]

23. Esplugas, S.; Bila, D.M.; Krause, L.G.T.; Dezotti, M. Ozonation and advanced oxidation technologies to remove endocrine disrupting chemicals (EDCs) and pharmaceuticals and personal care products (PPCPs) in water effluents. J. Hazard. Mater. 2007, 149, 631-642. [CrossRef]

24. Zimmermann, P.; Curtis, N. Antimicrobial Effects of Antipyretics. Antimicrob. Agents Chemother. 2017, 61, e02268-e02316. [CrossRef] [PubMed]

25. Sauvé, S.; Desrosiers, M. A review of what is an emerging contaminant. Chem. Cent. J. 2014, 8, 1-7. [CrossRef]

26. Wang, S.; Gunsch, C.K. Effects of selected pharmaceutically active compounds on the ammonia oxidizing bacterium Nitrosomonas europaea. Chemosphere 2011, 82, 565-572. [CrossRef] [PubMed]

27. Pennington, M.J.; Rothman, J.A.; Dudley, S.L.; Jones, M.B.; McFrederick, Q.S.; Gan, J.; Trumble, J.T. Contaminants of emerging concern affect Trichoplusia ni growth and development on artificial diets and a key host plant. Proc. Natl. Acad. Sci. USA 2017, 114, E9923-E9931. [CrossRef] [PubMed]

28. Pennington, M.J.; Rothman, J.A.; Jones, M.B.; McFrederick, Q.S.; Gan, J.; Trumble, J.T. Effects of contaminants of emerging concern on Myzus persicae (Sulzer, Hemiptera: Aphididae) biology and on their host plant Capsicum annuum. Environ. Monit. Assess. 2018, 190. [CrossRef] [PubMed]

29. Amariei, G.; Boltes, K.; Rosal, R.; Letón, P. Toxicological interactions of ibuprofen and triclosan on biological activity of activated sludge. J. Hazard. Mater. 2017, 334, 193-200. [CrossRef]

30. McMahon, P.B.; Chapelle, F.H. Microbial production of organic acids in aquitard sediments and its role in aquifer geochemistry. Nature 1991, 349, 233-235. [CrossRef]

31. Maeng, S.K.; Sharma, S.K.; Abel, C.D.T.; Magic-Knezev, A.; Amy, G.L. Role of biodegradation in the removal of pharmaceutically active compounds with different bulk organic matter characteristics through managed aquifer recharge: Batch and column studies. Water Res. 2011, 45, 4722-4736. [CrossRef] 
32. Greskowiak, J.; Prommer, H.; Massmann, G.; Nützmann, G. Modeling seasonal redox dynamics and the corresponding fate of the pharmaceutical residue phenazone during artificial recharge of groundwater. Environ. Sci. Technol. 2006, 40, 6615-6621. [CrossRef]

33. Alidina, M.; Li, D.; Drewes, J.E. Investigating the role for adaptation of the microbial community to transform trace organic chemicals during managed aquifer recharge. Water Res. 2014, 56, 172-180. [CrossRef]

34. Li, D.; Sharp, J.O.; Saikaly, P.E.; Ali, S.; Alidina, M.; Alarawi, M.S.; Keller, S.; Hoppe-Jones, C.; Drewes, J.E. Dissolved Organic Carbon Influences Microbial Community Composition and Diversity in Managed Aquifer Recharge Systems. Appl. Environ. Microbiol. 2012, 78, 6819-6828. [CrossRef] [PubMed]

35. Alidina, M.; Shewchuk, J.; Drewes, J.E. Effect of temperature on removal of trace organic chemicals in managed aquifer recharge systems. Chemosphere 2015, 122, 23-31. [CrossRef] [PubMed]

36. Tran, N.H.; Urase, T.; Ngo, H.H.; Hu, J.; Ong, S.L. Insight into metabolic and cometabolic activities of autotrophic and heterotrophic microorganisms in the biodegradation of emerging trace organic contaminants. Bioresour. Technol. 2013, 146, 721-731. [CrossRef] [PubMed]

37. Li, D.; Alidina, M.; Ouf, M.; Sharp, J.O.; Saikaly, P.; Drewes, J.E. Microbial community evolution during simulated managed aquifer recharge in response to different biodegradable dissolved organic carbon (BDOC) concentrations. Water Res. 2013, 47, 2421-2430. [CrossRef] [PubMed]

38. Chefetz, B.; Mualem, T.; Ben-Ari, J. Sorption and mobility of pharmaceutical compounds in soil irrigated with reclaimed wastewater. Chemosphere 2008, 73, 1335-1343. [CrossRef] [PubMed]

39. Johnson, R.M.; Sims, J.T. Influence of surface and subsoil properties on herbigide sorption by Atlantic Coastal Plain soils. Soil Sci. 1993, 155, 339-348. [CrossRef]

40. Xu, J.; Wu, L.; Chen, W.; Chang, A.C. Adsorption and degradation of ketoprofen in soils. J. Environ. Qual. 2009, 38, 1177-1182. [CrossRef]

41. Valhondo, C.; Martinez-Landa, L.; Carrera, J.; Ayora, C.; Nödler, K.; Licha, T. Evaluation of EOC removal processes during artificial recharge through a reactive barrier. Sci. Total Environ. 2018, 612, 985-994. [CrossRef]

42. Valhondo, C.; Martínez-Landa, L.; Carrera, J.; Díaz-Cruz, S.M.; Amalfitano, S.; Levantesi, C. Six artificial recharge pilot replicates to gain insight into water quality enhancement processes. Chemosphere 2020, 240, 124826. [CrossRef]

43. Barbieri, M.; Carrera, J.; Sanchez-Vila, X.; Ayora, C.; Cama, J.; Köck-Schulmeyer, M.; de Alda, M.; Barceló, D.; Tobella Brunet, J.; Hernández García, M. Microcosm experiments to control anaerobic redox conditions when studying the fate of organic micropollutants in aquifer material. J. Contam. Hydrol. 2011, 126, 330-345. [CrossRef]

44. Köck-Schulmeyer, M.; Ginebreda, A.; Postigo, C.; López-Serna, R.; Pérez, S.; Brix, R.; Llorca, M.; de Alda, M.L.; Petrovic, M.; Munnì, A.; et al. Wastewater reuse in Mediterranean semi-arid areas: The impact of discharges of tertiary treated sewage on the load of polar micro pollutants in the Llobregat river (NE Spain). Chemosphere 2011, 82, 670-678. [CrossRef]

45. Alidina, M.; Li, D.; Ouf, M.; Drewes, J.E. Role of primary substrate composition and concentration on attenuation of trace organic chemicals in managed aquifer recharge systems. J. Environ. Manag. 2014, 144, 58-66. [CrossRef] [PubMed]

46. Nödler, K.; Licha, T.; Bester, K.; Sauter, M. Development of a multi-residue analytical method, based on liquid chromatography-tandem mass spectrometry, for the simultaneous determination of 46 micro-contaminants in aqueous samples. J. Chromatogr. A 2010, 1217, 6511-6521. [CrossRef] [PubMed]

47. Gago-Ferrero, P.; Mastroianni, N.; Díaz-Cruz, M.S.; Barceló, D. Fully automated determination of nine ultraviolet filters and transformation products in natural waters and wastewaters by on-line solid phase extraction-liquid chromatography-tandem mass spectrometry. J. Chromatogr. A 2013, 1294, 106-116. [CrossRef]

48. European Parliament and the Council of the European Union. In Proceedings of the 96/23/EC Commission Decision of Implementing Council Directive 96/23/EC Concerning the Performance of Analytical Methods and the Interpretation of Results (Notified under Document Number C (2002) 3044) (Text withEEA Relevance) (2002/657/EC); Off J Eur communities 8-36; European Parliament and the Council of the European Union, Brussels, Belgium, 12 August 2002. [CrossRef] 
49. Valhondo, C.; Martinez-Landa, L.; Hidalgo, J.; Tubau, I.; De Pourcq, K.; Grau-Martinez, A.; Ayora, C. Tracer test Modeling for Local scale Residence Time Distribution characterization in an artificial recharge site. Hydrol. Earth Syst. Sci. 2016, 20, 4209-4221. [CrossRef]

50. Stuyfzand, P.J.; Segers, W.; van Rooijen, N. Behavior of Pharmaceuticals and Other Emerging Pollutants in Various Artificial Recharge Systems in The Netherlands; ISMAR: Arizona, AZ, USA; ACACIA: Arizona, AZ, USA, 2007; Volume 3, pp. 231-245.

51. Hidalgo, J.J.; Slooten, L.J.; Medina, A.; Carrera, J. A Newton-Raphson Based Code for Seawater Intrusion Modelling and Parameter Estimation. Available online: http://www.swim-site.nl/pdf/swim18_abstracts/ Hidalgo.pdf (accessed on 1 April 2020).

52. Medina, A.; Carrera, J. Coupled estimation of flow and solute transport parameters. Water Resour. Res. 1996, 32, 3063-3076. [CrossRef]

53. Medina, A.; Carrera, J. Geostatistical inversion of coupled problems: Dealing with computational burden and different types of data. J. Hydrol. 2003, 281, 251-264. [CrossRef]

54. Bertelkamp, C.; Schoutteten, K.; Vanhaecke, L.; Bussche, J.V.; Callewaert, C.; Boon, N.; Singhal, N.; van der Hoek, J.P.; Verliefde, A.R.D. A laboratory-scale column study comparing organic micropollutant removal and microbial diversity for two soil types. Sci. Total Environ. 2015, 536, 632-638. [CrossRef]

55. Regnery, J.; Wing, A.D.; Alidina, M.; Drewes, J.E. Biotransformation of trace organic chemicals during groundwater recharge: How useful are first-order rate constants? J. Contam. Hydrol. 2015, 179, 65-75. [CrossRef]

56. Schaffer, M.; Kröger, K.F.; Nödler, K.; Ayora, C.; Carrera, J.; Hernández, M.; Licha, T. Influence of a compost layer on the attenuation of 28 selected organic micropollutants under realistic soil aquifer treatment conditions: Insights from a large scale column experiment. Water Res. 2015, 74, 110-121. [CrossRef]

57. Grünheid, S.; Amy, G.; Jekel, M. Removal of bulk dissolved organic carbon (DOC) and trace organic compounds by bank filtration and artificial recharge. Water Res. 2005, 39, 3219-3228. [CrossRef] [PubMed]

58. Henzler, A.F.; Greskowiak, J.; Massmann, G. Modeling the fate of organic micropollutants during river bank filtration (Berlin, Germany). J. Contam. Hydrol. 2014, 156, 78-92. [CrossRef] [PubMed]

59. Laws, B.V.; Dickenson, E.R.V.; Johnson, T.A.; Snyder, S.A.; Drewes, J.E. Attenuation of contaminants of emerging concern during surface-spreading aquifer recharge. Sci. Total Environ. 2011, 409, 1087-1094. [CrossRef] [PubMed]

60. Nham, H.T.T.; Greskowiak, J.; Nödler, K.; Rahman, M.A.; Spachos, T.; Rusteberg, B.; Massmann, G.; Sauter, M.; Licha, T. Modeling the transport behavior of 16 emerging organic contaminants during soil aquifer treatment. Sci. Total Environ. 2015, 514, 450-458. [CrossRef]

61. Ranieri, E.; Verlicchi, P.; Young, T.M. Paracetamol removal in subsurface flow constructed wetlands. J. Hydrol. 2011, 404, 130-135. [CrossRef]

62. Wiese, B.; Massmann, G.; Jekel, M.; Heberer, T.; Dünnbier, U.; Orlikowski, D.; Grützmacher, G. Removal kinetics of organic compounds and sum parameters under field conditions for managed aquifer recharge. Water Res. 2011, 45, 4939-4950. [CrossRef]

63. Greskowiak, J.; Hamann, E.; Burke, V.; Massmann, G. The uncertainty of biodegradation rate constants of emerging organic compounds in soil and groundwater: A compilation of literature values for 82 substances. Water Res. 2017, 126, 122-133. [CrossRef]

64. Bertelkamp, C.; Reungoat, J.; Cornelissen, E.R.; Singhal, N.; Reynisson, J.; Cabo, A.J.; van der Hoek, J.P.; Verliefde, A.R.D. Sorption and biodegradation of organic micropollutants during river bank filtration: A laboratory column study. Water Res. 2014, 52, 231-241. [CrossRef]

65. Massmann, G.; Dünnbier, U.; Heberer, T.; Taute, T. Behaviour and redox sensitivity of pharmaceutical residues during bank filtration-Investigation of residues of phenazone-type analgesics. Chemosphere 2008, 71, 1476-1485. [CrossRef]

66. Barbieri, M.; Licha, T.; Nödler, K.; Carrera, J.; Ayora, C.; Sanchez-Vila, X. Fate of $\beta$-blockers in aquifer material under nitrate reducing conditions: Batch experiments. Chemosphere 2012, 89, 1272-1277. [CrossRef]

67. Liu, Y.-S.; Ying, G.-G.; Shareef, A.; Kookana, R.S. Biodegradation of three selected benzotriazoles in aquifer materials under aerobic and anaerobic conditions. J. Contam. Hydrol. 2013, 151, 131-139. [CrossRef] [PubMed] 
68. Maeng, S.K.; Sharma, S.K.; Lekkerkerker-Teunissen, K.; Amy, G.L. Occurrence and fate of bulk organic matter and pharmaceutically active compounds in managed aquifer recharge: A review. Water Res. 2011, 45, 3015-3033. [CrossRef] [PubMed]

69. Regnery, J.; Wing, A.D.; Kautz, J.; Drewes, J.E. Introducing sequential managed aquifer recharge technology (SMART) From laboratory to full-scale application. Chemosphere 2016, 154, 8-16. [CrossRef] [PubMed]

70. Hellauer, K.; Mergel, D.; Ruhl, A.S.; Filter, J.; Hübner, U.; Jekel, M.; Drewes, J.E. Advancing sequential managed aquifer recharge technology (SMART) using different intermediate oxidation processes. Water (Switzerland) 2017, 9, 221. [CrossRef]

71. Guchi, E. Review on Slow Sand Filtration in Removing Microbial Contamination and Particles from Drinking Water. Am. J. Food Nutr. 2015, 3, 47-55. [CrossRef]

72. Verma, S.; Daverey, A.; Sharma, A. Slow sand filtration for water and wastewater treatment-A review. Environ. Technol. Rev. 2017, 6, 47-58. [CrossRef]

73. Perez-Mercado, L.F.; Lalander, C.; Joel, A.; Ottoson, J.; Dalahmeh, S.; Vinnerås, B. Biochar filters as an on-farm treatment to reduce pathogens when irrigating with wastewater-polluted sources. J. Environ. Manag. 2019, 248, 109295. [CrossRef]

74. Matthess, G.; Pekdeger, A.; Schroeter, J. Persistence and transport of bacteria and viruses in groundwater-A concenptual evaluation. J. Contam. Hydrol. 1988, 2, 171-188. [CrossRef]

75. Kim, H.N.; Bradford, S.A.; Walker, S.L. Escherichia coli O157:H7 Transport in Saturated Porous Media: Role of Solution Chemistry and Surface Macromolecules. Environ. Sci. Technol. 2009, 43, 4340-4347. [CrossRef]

76. Park, Y.; Atwill, E.R.; Hou, L.; Packman, A.I.; Harter, T. Deposition of Cryptosporidium parvum Oocysts in porous media: A synthesis of attachment efficiencies measured under varying environmental conditions. Environ. Sci. Technol. 2012, 46, 9491-9500. [CrossRef]

77. Bichai, F.; Barbeau, B.; Dullemont, Y.; Hijnen, W. Role of predation by zooplankton in transport and fate of protozoan (oo)cysts in granular activated carbon filtration. Water Res. 2010, 44, 1072-1081. [CrossRef] [PubMed]

78. Sasidharan, S.; Bradford, S.A.; Šimunek, J.; Torkzaban, S. Minimizing virus transport in porous media by optimizing solid phase inactivation. J. Environ. Qual. 2018, 47, 1058-1067. [CrossRef] [PubMed]

79. Urfer, D. Use of bauxite for enhanced removal of bacteria in slow sand filters. Water Sci. Technol. Water Supply 2017, 17, 1007-1015. [CrossRef]

80. Weiss, W.J.; Bouwer, E.J.; Aboytes, R.; LeChevallier, M.W.; O’Melia, C.R.; Le, B.T.; Schwab, K.J. Riverbank filtration for control of microorganisms: Results from field monitoring. Water Res. 2005, 39, 1990-2001. [CrossRef] [PubMed]

81. Bekele, E.; Toze, S.; Patterson, B.; Higginson, S. Managed aquifer recharge of treated wastewater: Water quality changes resulting from infiltration through the vadose zone. Water Res. 2011, 45, 5764-5772. [CrossRef]

82. Betancourt, W.Q.; Kitajima, M.; Wing, A.D.; Regnery, J.; Drewes, J.E.; Pepper, I.L.; Gerba, C.P. Assessment of virus removal by managed aquifer recharge at three full-scale operations. J. Environ. Sci. Heal. Part A Toxic Hazard. Subst. Environ. Eng. 2014, 49, 1685-1692. [CrossRef]

83. Elkayam, R.; Aharoni, A.; Vaizel-Ohayon, D.; Katz, Y.; Negev, I.; Marano, R.B.; Cytryn, E.; Shtrasler, L.; Lev, O. Viral and Microbial Pathogens, Indicator Microorganisms, Microbial Source Tracking Indicators, and Antibiotic Resistance Genes in a Confined Managed Effluent Recharge System. J. Environ. Eng. 2018, 144, 05017011. [CrossRef]

84. Schijven, J.F.; Hassanizadeh, S.M. Removal of viruses by soil passage: Overview of modeling, processes, and parameters. Crit. Rev. Environ. Sci. Technol. 2000, 30, 49-127. [CrossRef]

85. Voigt, A.M.; Zacharias, N.; Timm, C.; Wasser, F.; Sib, E.; Skutlarek, D.; Parcina, M.; Schmithausen, R.M.; Schwartz, T.; Hembach, N.; et al. Association between antibiotic residues, antibiotic resistant bacteria and antibiotic resistance genes in anthropogenic wastewater-An evaluation of clinical influences. Chemosphere 2020, 241, 125032. [CrossRef]

86. Bengtsson-Palme, J.; Milakovic, M.; Švecová, H.; Ganjto, M.; Jonsson, V.; Grabic, R.; Udikovic-Kolic, N. Industrial wastewater treatment plant enriches antibiotic resistance genes and alters the structure of microbial communities. Water Res. 2019, 162, 437-445. [CrossRef]

87. Bengtsson-Palme, J.; Hammarén, R.; Pal, C.; Östman, M.; Björlenius, B.; Flach, C.F.; Fick, J.; Kristiansson, E.; Tysklind, M.; Larsson, D.G.J. Elucidating selection processes for antibiotic resistance in sewage treatment plants using metagenomics. Sci. Total Environ. 2016. [CrossRef] [PubMed] 
88. Berendonk, T.U.; Manaia, C.M.; Merlin, C.; Fatta-Kassinos, D.; Cytryn, E.; Walsh, F.; Bürgmann, H.; Sørum, H.; Norström, M.; Pons, M.N.; et al. Tackling antibiotic resistance: The environmental framework. Nat. Rev. Microbiol. 2015, 13, 310-317. [CrossRef] [PubMed]

89. Frieden, T. Antibiotic resistance threats in the United States. Cent. Dis. Control Prev. 2019, 1-114. [CrossRef]

90. Larsson, D.G.J.; Andremont, A.; Bengtsson-Palme, J.; Brandt, K.K.; de Roda Husman, A.M.; Fagerstedt, P.; Fick, J.; Flach, C.F.; Gaze, W.H.; Kuroda, M.; et al. Critical knowledge gaps and research needs related to the environmental dimensions of antibiotic resistance. Environ. Int. 2018, 117, 132-138. [CrossRef] [PubMed]

91. World Health Organisation (WHO). Global Action Plan on Antimicrobial Resistance; WHO: Geneva, Switzerland, 2017; pp. 1-28.

92. European Commission. A European One Health Action Plan against Antimicrobial Resistance; Commun FROM Comm TO Counc Eur Parliam; European Commission: Brussels, Belgium, 2017.

93. EU Decision 2018/840. Commission Implementing Decision (EU) 2018/840 of 5 June 2018. Off. J. Eur. Union. 2018, 141, 9-12.

94. Sharma, V.K.; Johnson, N.; Cizmas, L.; McDonald, T.J.; Kim, H. A review of the influence of treatment strategies on antibiotic resistant bacteria and antibiotic resistance genes. Chemosphere 2016. [CrossRef]

95. Gao, P.; Munir, M.; Xagoraraki, I. Correlation of tetracycline and sulfonamide antibiotics with corresponding resistance genes and resistant bacteria in a conventional municipal wastewater treatment plant. Sci. Total Environ. 2012. [CrossRef]

96. Li, J.; Cheng, W.; Xu, L.; Strong, P.J.; Chen, H. Antibiotic-resistant genes and antibiotic-resistant bacteria in the effluent of urban residential areas, hospitals, and a municipal wastewater treatment plant system. Environ. Sci. Pollut. Res. 2015, 22, 4587-4596. [CrossRef]

97. Pärnänen, K.M.M.; Narciso-da-Rocha, C.; Kneis, D.; Berendonk, T.U.; Cacace, D.; Do, T.T.; Elpers, C.; Fatta-Kassinos, D.; Henriques, I.; Jaeger, T.; et al. Antibiotic resistance in European wastewater treatment plants mirrors the pattern of clinical antibiotic resistance prevalence. Sci. Adv. 2019, 5, eaau9124. [CrossRef]

98. Ju, F.; Beck, K.; Yin, X.; Maccagnan, A.; McArdell, C.S.; Singer, H.P.; Johnson, D.R.; Zhang, T.; Bürgmann, H. Wastewater treatment plant resistomes are shaped by bacterial composition, genetic exchange, and upregulated expression in the effluent microbiomes. ISME J. 2019, 13, 346-360. [CrossRef]

99. Du, J.; Geng, J.; Ren, H.; Ding, L.; Xu, K.; Zhang, Y. Variation of antibiotic resistance genes in municipal wastewater treatment plant with A2O-MBR system. Environ. Sci. Pollut. Res. 2015, 22, 3715-3726. [CrossRef] [PubMed]

100. Fang, H.; Zhang, Q.; Nie, X.; Chen, B.; Xiao, Y.; Zhou, Q.; Liao, W.; Liang, X. Occurrence and elimination of antibiotic resistance genes in a long-term operation integrated surface flow constructed wetland. Chemosphere 2017. [CrossRef] [PubMed]

101. Cui, E.; Wu, Y.; Zuo, Y.; Chen, H. Effect of different biochars on antibiotic resistance genes and bacterial community during chicken manure composting. Bioresour. Technol. 2016. [CrossRef] [PubMed]

102. Taylor, E.N.; Kummer, K.M.; Durmus, N.G.; Leuba, K.; Tarquinio, K.M.; Webster, T.J. Superparamagnetic iron oxide nanoparticles (SPION) for the treatment of antibiotic-resistant biofilms. Small 2012, 8, 3016-3027. [CrossRef]

103. Nijhawan, A.; Labhasetwar, P.; Jain, P.; Rahate, M. Public consultation on artificial aquifer recharge using treated municipal wastewater. Resour. Conserv. Recycl. 2013. [CrossRef]

104. Smith, H.M.; Brouwer, S.; Jeffrey, P.; Frijns, J. Public responses to water reuse-Understanding the evidence. J. Environ. Manag. 2018, 207, 43-50. [CrossRef]

105. Lazarova, V.; Asano, T.; Bahri, A.; Anderson, J. Milestones in Water Reuse: The Best Success Stories; IWA Publishing: London, UK, 2013.

106. Hartley, T.W. Public perception and participation in water reuse. Desalination 2006, 187, 115-126. [CrossRef]

107. Hurlimann, A.; Dolnicar, S. When public opposition defeats alternative water projects-The case of Toowoomba Australia. Water Res. 2010, 44, 287-297. [CrossRef]

(C) 2020 by the authors. Licensee MDPI, Basel, Switzerland. This article is an open access article distributed under the terms and conditions of the Creative Commons Attribution (CC BY) license (http://creativecommons.org/licenses/by/4.0/). 